\title{
Canção do Amor Demais: marco da música popular brasileira contemporânea
}

\author{
Liliana Harb Bollos (Faculdade de Música Carlos Gomes, EMESP Tom Jobim, São Paulo, SP) \\ lilianabollos@uol.com.br
}

\begin{abstract}
Resumo: Discussão sobre a importância do LP Canção do Amor Demais dentro do panorama da cultura brasileira, mais do que do âmbito da música popular em si, a partir do texto de Vinícius de Moraes na contracapa do disco e da crítica de José da Veiga Oliveira. A fronteira existente entre o popular e erudito fica menos evidente neste disco, por conta do alto grau composicional das canções e pelos arranjos assinados por Jobim, tendo em vista que ali se deu a apresentação de João Gilberto em disco e da batida do violão que iria simbolizar a Bossa Nova.

Palavras-chave: Bossa Nova; Tom Jobim; Vinícius de Morais; João Gilberto; José da Veiga Oliveira; Música Popular Brasileira; Jornalismo Cultural; Cultura Brasileira.
\end{abstract}

\section{Canção do Amor Demais [Song of Too Much Love]: a milestone in contemporary Brazilian po- pular music}

Abstract: This article discusses the importance of the LP Canção do Amor Demais (Song of Too Much Love) within the panorama of Brazilian culture, much more than simply within the area of popular music itself. As the a starting point, this discussion uses the LP's liner notes by Vinícius de Moraes and the critique by José da Veiga Oliveira to demonstrate that the existing border between popular classical music become less evident with this album. This is due to the high compositional quality of the songs and arrangements by Tom Jobim, the introduction of João Gilberto and the guitar rhythms that would come to symbolize bossa nova.

Keywords: Bossa Nova; Tom Jobim; Vinícius de Morais; João Gilberto; José da Veiga Oliveira; Brazilian Popular Music; Cultural Journalism; Brazilian Culture.

\section{Introdução}

É sabido que a Bossa Nova surgiu no cenário musical brasileiro em meados de 1958 com a canção Chega de Saudade (Antônio Carlos Jobim/Vinícius de Moraes), interpretada pelo cantor e violonista João Gilberto e foi alvo da primeira grande manifestação de crítica de música popular nos jornais brasileiros. Muitos autores também mencionam a importância do LP Canção do amor demais (Festa, FT1801) da cantora Elizete Cardoso, por causa da participação de João Gilberto ao violão nesse disco. Mas esse disco nos trouxe algumas outras características imprescindiveis para que entendamos o fenômeno Bossa Nova dentro do panorama da cultura brasileira, mais do que do âmbito da música popular em si.

A cantora Elizete Cardoso fora convidada por Vinícius de Moraes e Tom Jobim para participar do projeto idealizado pelo proprietário do selo Festa, Irineu Garcia, de unir a música e a poesia de ambos em disco. João Gilberto já se apresentava na noite carioca em 1957 e Jobim, que ficara impressionado com o som inovador do cantor baiano, convidou Gilberto para participar do disco da cantora, acompanhando-a ao violão em duas faixas do disco:
"Chega de Saudade" (Jobim/Moraes) e "Outra vez" (Jobim). Pela primeira vez a batida que simbolizaria a bossa nova estava sendo gravada, porém a forma de cantar de Elizete Cardoso era ainda convencional, a acentuação ritmica das silabas tônicas sempre se dava nos tempos fortes e o uso do vibrato ainda persistia. Essa caracteristica vocal da geração do samba-canção que João Gilberto passou a abolir a partir de sua volta ao Rio de Janeiro em 1957, seria utilizada por ele no início de sua carreira, quando chegou à capital federal para integrar o grupovocal Garotos da Lua como o novo crooner em 1950.

A forma com que o violão foi tocado, simplificando o samba e ao mesmo tempo fazendo uso de harmonia mais sofisticada e densa, provocou uma reação imediata de músicos, críticos, e também da gravadora Odeon, que instantaneamente convidou Gilberto a gravar o seu primeiro single, com "Chega de Saudade" de um lado e "Bim Bom" (João Gilberto) do outro, poucos meses depois do disco da cantora. Em sua coluna para o Diário Carioca, em 29/01/1965, Vinícius de Moraes relata o nascimento da canção "Chega de saudade": 
Um samba todo em voltas, onde cada compasso era uma queixa de amor, cada nota uma saudade de alguém longe. Mas a letra não vinha. Fiz 10, 20 tentativas. Uma manhã, depois da praia, subitamente a resolução chegou. Queria, depois dos sambas do Orfeu, apresentar ao meu parceiro uma letra digna de sua nova música: pois eu realmente a sentia nova, caminhando numa direção a que não saberia dar nome ainda, mas cujo nome já estava implícito na criação. Era realmente a bossa nova que nascia, a pedir apenas, na sua interpretação, a divisão que João Gilberto descobriria logo depois (MORAES, 29/01/1965).

Não por acaso o LP Canção do Amor Demais teve uma importância fundamental para a música brasileira. Além do violão de Gilberto nas duas faixas, todos os arranjos do disco levam a assinatura de Tom Jobim, ainda desconhecido da grande mídia, apesar de ter musicado a peça de teatro Orfeu da Conceição de Vinícius de Moraes em 1956, alcançando prestígio e reputação. 0 que causou espanto, afinal, neste disco? Alguns músicos comentavam sobre a "batida" diferente do violão de Gilberto, porém, a recepção do disco foi bastante tímida, com a exceção do texto de José da Veiga Oliveira, estampado no "Suplemento literário" do jornal O Estado de S.Paulo, razão pela qual acreditamos que os músicos eram os mais interessados naquele disco, e não a crítica.

Quando o cantor e violonista João Gilberto lançou o seu primeiro single com "Chega de Saudade" e "Bim Bom", ainda em 1958, poucos meses depois de ter participado do LP de Elizete Cardoso, o público imediatamente notou a originalidade, ou pelo menos, a estranheza daquela música, quando as rádios começaram a tocar. 0 impacto que essa música provocou foi enorme, considerada um verdadeiro divisor de águas, gerando as primeiras criticas jornalísticas, mas também influenciando o estilo de compor de vários músicos. Em pouco tempo o cantor baiano impôs um novo padrão estético à música popular brasileira, inventando um diálogo entre a voz e o violão, transformando o violão em instrumento participante do processo criativo e não somente um "acompanhante" da voz, tão comum na época. A batida que ele imprimiu, desde a sua primeira gravação com Elizete Cardoso no LP Canção do amor demais, foi decisiva para que muitos jovens se interessassem em tocar esse instrumento.

0 próprio poeta Manuel BANDEIRA disse que "para nós brasileiros, o violão tinha que ser o instrumento nacional, racial" (1955, p. 8). Ao contrário do piano, introduzido nas casas da alta classe média no século dezenove, o violão foi escolhido pela classe menos favorecida, evidentemente por ser mais barato e portátil, transformandose no instrumento mais significativo da música popular brasileira, percorrendo o choro, o samba, a bossa nova, com desenvoltura, durante todo o século XX. João Gilberto, por sua vez, conseguiu com que o violão migrasse também para a classe média, impondo ao violão um lugar não somente nas rodas de samba, mas também nas casas de concerto. Vimos, a partir de Gilberto, que o violão começou a ser utilizado na música norte-americana, muitas vezes substituindo o piano como instrumento harmônico predileto, criando uma contraposição clara entre os grupos de jazz, que têm o piano como instrumento central (acompanhado de contrabaixo e bateria) e a nova sonoridade adquirida pelo violão. Com isso, o violão toma 0 lugar do piano, criando uma sonoridade "nacional", brasileira, marca de um estilo inconfundivel que João Gilberto, a partir de "Chega de Saudade", consagrou.

No entanto, ainda hoje ouvimos que a batida do violão é que chamou a atenção no disco Canção do Amor Demais, e não as composições ou tampouco os arranjos do disco. $\mathrm{Na}$ verdade, nesses arranjos tão pouco comentados é que estão a chave da renovação. Jobim preferiu conferir um caráter quase camerístico ao disco de Elizete Cardoso, simplificando sua instrumentação, fazendo uso de poucos instrumentos, abrindo, assim, espaço para o violão em algumas músicas. Notemos que as treze canções do disco possuem orquestrações muito diferentes uma das outras, sendo que algumas canções foram interpretadas quase $a$ capela, acompanhadas somente de piano e contrabaixo. Nessa época, os pesados arranjos orquestrais eram baseados em uma voz condutora acompanhada por uma orquestra que Ihe servia de base, ou seja, não havia um jogo contrapontístico de vozes e instrumentos que pudessem participar do arranjo, como foi o caso desse disco.

Assim, a transição do samba tradicional para a bossa nova fazia-se presente não somente na batida do violão de Gilberto, mas sobretudo na voz ritmicamente convencional da cantora contrastando com os arranjos econômicos de Jobim, sintetizados nesse disco com uma harmonia densa, rica, difícil, considerada pelos opositores como influência direta do jazz americano. Infelizmente, poucos críticos perceberam que a influência benéfica desses arranjos veio também de grandes músicos brasileiros, como Villa-Lobos, Cláudio Santoro, Léo Perachi, Radamés Gnatalli e também do professor de Jobim, H. J. Koellreutter e de outros grandes compositores universais como Chopin, Debussy e Ravel, para citar somente três.

Muito embora consideremos que a música erudita, de modo geral, foi uma influência mais significativa em Tom Jobim do que em outros músicos da bossa nova, a relação desses dois ambientes musicais - erudito e popular - se propagou por toda a obra jobiniana. Portanto, não há como reduzir o trabalho composicional ou pianístico de Jobim somente dentro dos parâmetros da música popular, se é que realmente podemos fazer algum julgamento neste sentido, mas é sabido que Jobim foi aluno de piano de Lúcia Branco e Tomás Terán, além de ter estudado harmonia com Hans Joachin Koellreuter. Este último afirmou que ele teria passado a Jobim noções de harmonia e contraponto clássicos e "rudimentos de execução pianística", pois o que interessava ao professor era dar ao aluno uma instrução "globalizante" (KOELLREUTTER apud Cabral, p.45).

\section{0 disco Canção do amor demais revisitado por Vinícius de Moraes}

0 repertório do disco, como já dissemos, é todo composto de músicas da parceria Jobim-Vinícius, porém, das treze canções do disco, nove ("Chega de saudade", "Caminho de 
pedra", "Luciana", "Janelas abertas", "Eu não existo sem você", "Estrada branca", "Vida bela", "Modinha", "Canção do amor demais") são parcerias de Jobim e Vinícius de Moraes, duas ("Serenata do adeus", "Medo de amar") são composições somente de Vinícius e duas ("As praias desertas", "Outra vez") pertencem somente a Jobim, o que reforça que o projeto estava focado na obra de Vinícius e Jobim e não na cantora Elizete Cardoso, convidada por eles para integrar o projeto. A contracapa do disco também merece destaque, pois há um texto de Vinícius de MORAES que elucida bem o projeto da parceira, transcrito parcialmente abaixo:

\begin{abstract}
Dois anos são passados desde que Antonio Carlos Jobim (Tom, se preferirem) e eu nos associamos para fazer os sambas de minha peça "Orfeu da Conceição", de que restou um grande sucesso popular, "Se Todos Fossem Iguais a Você" e, sobretudo, uma grande amizade. (...)
\end{abstract}

Este LP, que se deve ao ânimo de Irineu Garcia, é a maior prova que podemos dar da sinceridade dessa amizade e dessa parceria. (...)

Nem com este LP queremos provar nada, senão mostrar uma etapa do nosso caminho de amigos e parceiros no divertidíssimo labor de fazer sambas e canções, que são brasileiros mas sem nacionalismos exaltados, e dar alimento aos que gostam de cantar, que é coisa que ajuda a viver.

A graça e originalidade dos arranjos de Antonio Carlos Jobim não constituem mais novidade, para que eu volte a falar delas aqui. Mas gostaria de chamar a atenção para a crescente simplicidade e organicidade de suas melodias e harmonias, cada vez mais libertas da tendência um quanto mórbida e abstrata que tiveram um dia. 0 que mostra a inteligência de sua sensibilidade, atenta aos dilemas do seu tempo, e a construtividade do seu espírito, voltado para os valores permanentes na relação humana (MORAES, 1958).

Vinícius reitera o motivo pelo qual Elizete Cardoso foi escoIhida para fazer esse trabalho, muito embora tenha sido Dolores Duran convidada primeiramente, mas acabou pedindo um cachê alto demais para o humilde selo Festa (CASTRO, 2002, p. 176). Nesse sentido, a escolha por Elizete veio ao encontro do gosto dos compositores, uma vez que Dolores era a escolha de Irineu Garcia, dono do selo. Em seu texto, Vinícius expõe com cuidado que o tipo de voz dela "respira acima do popular", assim como a música do disco:

\begin{abstract}
Não foi somente por amizade que Elizete Cardoso foi escolhida para cantar este LP. É claro que, por ela interpretado, ele nos acrescenta ainda mais, pois fica sendo a obra conjunta de três grandes amigos; gente que se quer bem para valer; gente que pode, em qualquer circunstância, contar um com o outro; gente, sobretudo, se danando para estrelismos e vaidades e glórias. Mas a diversidade dos sambas e canções exigia também uma voz particularmente afinada; de timbre popular brasileiro mas podendo respirar acima do puramente popular; com um registro amplo e natural nos graves e agudos e, principalmente, uma voz experiente, com a pungência dos que amaram e sofreram, crestada pela pátina da vida. E assim foi que a Divina impôs-se como a lua para uma noite de serenata (MORAES, 1958).
\end{abstract}

Uma tradição que se formou a partir dessa época da Bossa Nova é que os encartes dos long-playng eram verdadeiras obras de arte, contendo fotos e gravuras de artistas plásticos, herança do Modernismo, época em que Di Cavalcanti, Tarsila do Amaral, entre outros, desenharam várias capas de livros. Em 2005 foi publicado o livro Bossa
Nova e Outras Bossas - A Arte e o Design das Capas dos LPs de Caetano RODRIGUES e Charles GAVIN (Viva Rio/ Petrobrás), justamente sobre este assunto. No caso dos LPs, além do trabalho gráfico interessante, apareceram os textos de apresentação nas contracapas dos discos. É o caso de Vinícius de Moraes que apresenta o disco de Elizete Cardoso, expondo de forma carinhosa o projeto, assim como Tom Jobim faz a apresentação no disco Chega de Saudade de João Gilberto. Aliás, nesse disco apareceu palavra bossa nova duas vezes, numa época em que ainda não se sabia como chamar aquela nova música. Na letra de "Desafinado" ("isto é bossa nova, isto é muito natural") e no texto de Jobim em que ele afirma que "João Gilberto é um baiano "bossa-nova" de vinte e seis anos. Em pouquíssimo tempo, influenciou toda uma geração de arranjadores, guitarristas, músicos e cantores" (JOBIM, 1959).

Chamamos a atenção ainda para as palavras de Vinícius de Moraes, quando este se refere às composições de Canção do amor demais como sambas e canções, afinal, no decorrer de sua evolução, o samba tem recebido características próprias da evolução de seu tempo, de sua gente, de seus intérpretes, de seus músicos, então, nada mais natural que ele se refira a sambas, quando o andamento da composição for mais rápido e a canções para músicas mais lentas. 0 importante, para Vinícius, é "mostrar uma etapa do caminho de amigos e parceiros no divertidissimo labor de fazer sambas e canções, que são brasileiros, mas sem nacionalismos exaltados" (MORAES, 1958), essa dimensão menos historicista e mais estética que ele anteviu, o que realmente iria acontecer com o lançamento do disco Chega de saudade de João Gilberto.

Certamente Canção do amor demais foi um marco da música popular brasileira contemporânea, tanto pela concepção moderna e inventiva dos arranjos e composições, quanto pela participação de Jobim, Vinícius e João Gilberto na concepção e confecção do disco. No entanto, não nos esqueçamos de que não foi por acaso que esses três artistas foram considerados os mentores de uma nova proposta musical que estava surgindo, uma vez que a obra (o disco) que eles realizaram era uma busca

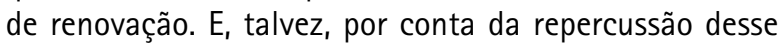
disco, que se tornou o disco de apresentação da bossa nova, João Gilberto gravaria o single "Chega de Saudade" e "Bim bom", alguns meses mais tarde.

Assunto que tem inspirado muitas polêmicas e discussões, tanto por parte de entusiastas quanto de opositores, a bossa nova surgiu de uma série de acontecimentos e influências, como qualquer outra obra artística nova, impregnada de novas características renovadoras advindas de várias fontes. Como não dizer que o jazz, sobretudo o cool jazz, influenciou e muito os músicos brasileiros que deram origem a esse movimento? Mas alguns músicos brasileiros da chamada Época de Ouro, como Custódio Mesquita ou Ary Barroso, também tomaram conhecimento da música americana e tampouco foram questionados quanto às suas influências americanas dentro de suas canções. 
De fato, a influência que a música popular americana exerceu em todo o mundo é grande. Em meados de 1950, época em que os programadores de rádio, juntamente com as grandes gravadoras de discos, detinham poder e impunham o gosto musical, alguns artistas brasileiros que buscavam uma saída para aquela música abolerada, imposta pelos meios de comunicação, aproximaram-se do novo estilo que estava se formando nos Estados Unidos, o cool jazz. Com características quase camerísticas como suavidade, pausas, contraponto e harmonização sutil, esse estilo de jazz se impôs, nos anos 1950, procurando se distanciar do modo nervoso do estilo bebop. Entre os principais representantes do cool jazz destacam-se os saxofonistas Gerry Mulligan, Paul Desmond, Lee Konitz e Stan Getz, o trompetista Chet Baker e o pianista Lennie Tristano, mas foram o arranjador Gil Evans e o trompetista Miles Davis, ao lançar o LP The Birth of the Cool (Capitol, M-11026) em 1949 que estabeleceram esse novo estilo de jazz.

Em certa medida, a Bossa Nova realmente sofreu influência do estilo cool jazz em vários aspectos, como por exemplo, pela redução de instrumentos acompanhantes, gerando uma diminuição do volume do arranjo, sobressaindo, assim, o arranjo musical e, por conseguinte, a voz condutora. 0 cantor passa a se exprimir sem força, sem vibrato, mais suavemente, exercitando na voz a possibilidade de um instrumento de sopro. Alguns artistas norte-americanos foram muito apreciados por músicos bossanovistas, como 0 trompetista e cantor Chet Baker, sobretudo o disco The best of Chet Baker sings (Pacific-EUA 792932, 1953) e a cantora Julie London com o disco Julie is her name (EMI-Br 799804, 1955), com o guitarrista Barney Kessel.

Entretanto, além da influência do jazz, consideramos vários outros fatores que foram imprescindiveis para o surgimento da bossa nova, tais como o trabalho que estava sendo desenvolvido por diversos artistas na época que traziam características inovadoras como os cantores Dick Farney e Lúcio Alves, o conjunto-vocal Os Cariocas, os violonistas Garoto e Luis Bonfá, o arranjador Radamés Gnatalli, o pianista e compositor Johnny Alf, os compositores da Geração de Ouro Dorival Caymmi e Ary Barroso (para ficar somente nesses nomes) e, como não poderia deixar de mencionar, a grande contribuição da música erudita brasileira, entre outros, Villa-Lobos, Hans-Joachin Koellreutter e Cláudio Santoro, todos presentes na música de Jobim.

Este último já se aliara em parceria com Vinícius de Moraes em 1955, cujo trabalho resultou na obra Canções de Amor (para canto e piano), uma seleção de canções musicadas por Santoro sobre poemas de Vinícius, que mostrou a Jobim quando se conheceram. Há, dentro do ambiente musical, muitas ressalvas quanto à influência de Santoro sobre a obra de Jobim, inclusive os que defendem a possibilidade de plágio por parte de Jobim. Não podemos nos esquecer de que, à medida que se estuda, analisa e aprende uma obra, a assimilação ocorre inevitavelmente. Acreditamos que a música de Jobim é tão fenomenal porque teve muitas assimilações que a enriqueceram excepcionalmente.

De fato, essas primeiras manifestações de renovação só demonstram o quanto significativa aquela música em formação viria a se tornar. Se a bossa nova se impõe ao deslocar alguns códigos de convenções musicais vigentes até então, como por exemplo, a dissonância moderna de "Desafinado", quando sua letra reitera que "isto é bossa nova, isto é muito natural", o disco Canção do amor demais de Elizete Cardoso apresenta, de uma só vez, as três figuras mais proeminentes da música popular moderna: João Gilberto, Tom Jobim e Vinícius de Moraes.

\section{Música e crítica por Veiga Oliveira: análise e compreensão à altura do disco}

A recepção do LP Canção do amor demais, lançado em abril de 1958, foi tímida, com exceção de uma resenha que merece especial atenção, pois propõe, sem ressentimentos, uma leitura construtiva acerca do novo disco. Publicada no lendário "Suplemento literário" do jornal $O$ Estado de $S$. Paulo em 28/02/1959, muitos meses depois do lançamento musical, a crítica "Canções de modinhas nossas" do crítico, musicólogo e professor José da Veiga Oliveira comenta dois discos recém-publicados, Canção do amor demais e Modinhas fora de moda da soprano Lenita Bruno.

0 Suplemento Literário era uma das publicações jornalísticas mais prestigiosas da época e tornou-se uma espécie de ponte importante entre a universidade e imprensa, tendo como colaboradores críticos do Grupo Clima como Antônio Candido, Décio de Almeida Prado, Ruy Coelho, Antonio Branco Lefèvre, Álvaro Bittencourt e Alberto Soares de Almeida, entre outros. Esses intelectuais, primeiros formandos e depois professores da Faculdade de Filosofia da USP, foram os responsáveis pela publicação da revista Clima na década de 1940, que reuniu ensaios acadêmicos em diversas áreas. Esta publicação praticamente definiu o destino intelectual do grupo e representou a entrada de cena de uma geração importante de críticos que iria convergir contato entre universidade e público, cultura e comunicação.

Tivemos a oportunidade de pesquisar no Instituto de Estudos Brasileiros (IEB-USP) cerca de 344 resenhas de música do Suplemento Literário do jornal 0 Estado de $S$. Paulo, desde o primeiro número do suplemento, de 06/10/1956 até 29/06/1963, sete meses depois do famoso concerto no Carnegie Hall, tempo suficiente, portanto, para que houvesse alguma outra publicação sobre a bossa nova nesse caderno. Não houve. 0 único texto que emite comentário sobre algum integrante do movimento é o de José da Veiga Oliveira. Pela relevância da crítica e importância da publicação em jornal de grande projeção, detenhamo-nos à análise e transcrição parcial da crítica sobre o lançamento do novo disco de Elizete Cardoso:

A "Canção do Amor Demais" (Festa, LDV 6002) obteve grande aceitação por quatro motivos: a música admiravelmente comunicativa de Antonio Carlos Jobim, a poesia de Vinícius de Morais, a voz 
cálida e flexível de Elizete Cardoso e um registro sonoro dos mais perfeitos já produzidos no país.

Primeira indagação: será música popular ou erudita? Daquela possui todos os elementos de ritmo, imagens, motivos, colorido, menos o primarismo do conteúdo poético, a harmonia grosseira, defectiva e rudimentar. Música erudita ainda não é, muito embora algumas das melodias estejam próximas aos melhores "Lieder". A singularidade dessas partituras reside na ambivalência, situadas na mui imprecisa fronteira que permeia os dois gêneros. Poderse-ia considerar a "Canção do Amor Demais" como um ciclo de melodias ("Liederkreis") à maneira dos de Schumann sobre textos de Heine ou Eichendorff. Sem nenhum tema poético que sirva de motivo-condutor ("Leitmotiv") recorrente ou unitário, observa-se, todavia, uma unidade de escrita musical ("durchkomponiert") que permite ouvir todo o microssulco qual uma única melodia distribuida entre várias partes, sem que o plano artístico se veja afetado (OLIVEIRA, O Estado de S. Paulo, 28/02/1959).

Ao lançar um olhar à obra, o crítico expõe sua dúvida diante da música que encontra no disco, ao mesmo tempo que propõe uma leitura construtiva sobre a suposta fronteira entre o erudito e popular. Oliveira questiona 0 pertencimento do disco ("Primeira indagação: será música popular ou erudita?") ao propor uma questão, e não afirmar, como a maioria faz, com pontualidade e agudez, em qual tipo de música esse disco estaria inserido, se na música popular ou na erudita. 0 que ainda não sabiamos na época era que aquela música iria desencadear algo novo no cenário da música popular no Brasil, uma espécie de erupção de criatividade no campo de uma música que não era erudita mais, era popular, mas um popular mais sofisticado, cerebral, sutil, inovador. Acreditamos que essa música popular nada mais é do que uma nova tradição da música popular brasileira com características eruditas, dentro de um âmbito particularmente envolvido com questões de mercado e cultura de massa, cujo principal representante é Tom Jobim.

Na primeira frase de sua critica, Veiga Oliveira delineia os motivos pelos quais o disco tinha sido aceito: "a música admiravelmente comunicativa de Antonio Carlos Jobim, a poesia de Vinícius de Morais (grafado com 'i' pelo crítico), a voz cálida e flexível de Elizete Cardoso e um registro sonoro dos mais perfeitos já produzidos no país". Tínhamos evidências, portanto, de que o crítico realmente tentou compreender a obra. Depois de afirmar que, embora tenha elementos da música popular (ritmo, imagens, motivos, colorido), seu conteúdo poético e harmonia estão mais para o outro gênero musical (erudito), situando a obra na "imprecisa fronteira que permeia os dois gêneros". Não podemos deixar de mencionar que Jobim estudou com professores da chamada música de vanguarda, erudita, como Koellreutter e popular, como Léo Perachi e sobretudo Radamés Gnatalli. Este último foi um dos primeiros músicos a transitar com fluência pelos dois mundos da música, por isso essa capacidade dele em situar-se no popular, apropriando-se ao mesmo tempo de elementos mais sofisticados, próprios do mundo erudito, do qual o crítico muito bem conhece. Oliveira segue seu texto comparando o lied alemão com as canções do disco:

0 que mais me impressionou foi a fusão indestrutivel de poesia e música, funcionando uma como complemento da outra.
Desnecessário seria ressaltar tal circunstância em nossa canção de câmara. Dai a citação dos dois grandes poetas românticos alemães do século XIX, cujos textos encontraram compositores à altura (Goethe e Moericke; Schubert e Wolf poderiamos trazer, também, à colação).

Longe de mim a audácia de estabelecer apressadas equiparações entre obras definitivamente incorporadas ao patrimônio artístico universal e o ciclo de Jobim-Vinícius, sobre o qual só o tempo dirá de sua permanência no repertório.

Disse Marcel Beaurfils a propósito do binômio verbo-música no "Lied": "O Lied acha-se ligado a seu texto. 0 menor desvio da palavra torna-se sua ferida, seu impudor, sua tolice. Tudo se passa numa concentração de espaço e dos sentidos, onde a atenção nada dissocia, onde nenhuma ficção desvia nem anestesia. Texto e som: tudo é gravado. Quando o Lied se alarga para o grande painel, a margem de liberdade reaparece. Quando ele se comprime num medalhão, ai nenhum artifício é mais possivel, nenhuma falta contra o pensamento e o bom gosto" (OLIVEIRA, 1959).

Ao estabelecer comparações entre a letra-música de Vinícius-Jobim e o Lied alemão de Schumann-Heine, 0 crítico consegue perceber "a fusão indestrutivel de poesia e música, funcionando uma como complemento da outra", estabelecendo, desse modo, um elo entre a alta poesia de Vinícius de Moraes e Goethe, assim como a música sofisticada de Jobim e Schubert. Em seguida, o crítico faz um comentário de cada faixa do disco, iniciando sua análise por "Chega de saudade" (Jobim/Moraes), a canção que abre o disco:

\footnotetext{
"Chega de saudade", um samba, abre a primeira faixa, introduzindo o ouvinte à "Serenata do Adeus", uma das melodias mais apreciadas da série. "Pizzicatti" dos contrabaixos, saxofone em plangentes escalas descendentes, além de trombone em "staccato". A linha melódica converte-se, por vezes, num recitativo modulatório, que só uma artista como Elizete Cardoso poderia interpretar com verdadeira dignidade artística (OLIVEIRA, 1959).
}

Curiosamente, apesar de ter sido "Chega de saudade" a canção que mais chamou a atenção do disco, lançada há quase um ano antes desta crítica, seja pela riqueza e originalidade da composição ou pelo acompanhamento de João Gilberto ao violão, ela não recebe qualquer análise do crítico, que segue sua análise com a próxima música, "Serenata do adeus" (Moraes). Nesta música o crítico destaca a melodia do saxofone, mas na verdade o instrumento que é tocado na gravação e tem destaque é o clarone, seja na introdução, quando abre a faixa, acompanhado em seguida de cordas ou fazendo contracanto com a voz. Também têm evidência, em momentos distintos da música, os trombones (com surdina), as madeiras (que preparam o canto), a harpa e o violoncello (em pizzacato), em arranjo primoroso de Jobim. No arranjo, cada instrumento tem uma intenção, por vezes mínima, onde sobressai a voz da cantora Elizete Cardoso, formando, assim, um trio perfeito de composição-arranjo-interpretação. Veiga Oliveira segue sua análise com "As praias desertas" (Jobim) e "Caminho de pedra" (Jobim/Moraes):

"As praias desertas": imagens poéticas de imensos horizontes marinhos. A harmonia, como não poderia deixar de ser, é de feitio improvisatório, impressionista. Piano, discreta percussão. Flauta, figuras rítmicas das cordas no registro médio imitam o ranger do carro de bois: "Caminho de pedra". Nessa melodia encontramos a "Wande- 
rung" dos românticos alemães, a caminhada infinda. A música como que move-se, anda suavemente, ao ponto das palavras expirarem em melismas imponderáveis, à distância (OLIVEIRA, 1959).

Enquanto "Serenata do adeus", uma balada grave e emocional, não recebe acompanhamento de seção rítmica, mas um arranjo farto de instrumentos orquestrais, a terceira faixa, "As praias desertas", tem uma introdução com flautas, com acompanhamento de bateria, contrabaixo e piano, este último faz contracantos com a voz durante toda a música. Aliás, como o próprio Vinícius de Moraes escreve que o disco é composto por sambas e canções, esta faixa é um samba-canção, por assim dizer, moderno, com acompanhamento leve, sutil. 0 que o crítico escreve como "discreta percussão" são vários acordes arpejados que o piano faz interpondose à voz de Elizete Cardoso. Para ele, esses arpejos são colocados como sussurros. Já em "Caminho de pedra" (Jobim/Moraes), o violão é presente durante toda a música desde a introdução com a flauta, enquanto que a trompa é o instrumento que imita o ranger do carro de bois, de caráter impressionista. Novamente o crítico faz analogia ao Romantismo alemão, trazendo o disco para o universo clássico, seguindo com sua análise:

\begin{abstract}
"Luciana" apresenta um tempo de valsa, o clássico 3/4. Canção embaladora, valsa brasileira. "Janelas abertas" realiza-se através de belíssima poesia, repleta de luz e sombra, cativeiro e libertação da alma. Jobim traduziu perfeitamente o texto de Vinícius. Mui apreciado tornou-se "Eu não existo sem você". No instrumental, predomina o violão. Rica harmonia das cordas, com apoio de "pizzicatti" dos contrabaixos. "Outra vez" é um samba-canção com violinos em contracanto, violão e percussão. Canção nostálgica, dolente, reticente é "Medo de amar": "Vire esta folha do livro e se esqueça de mim..." (OLIVEIRA, 1959).
\end{abstract}

Em "Janelas abertas" (Jobim/Moraes), temos novamente um samba-canção de caráter pré-bossanovista, em que a voz de Elizete Cardoso compõe o arranjo de forma primorosa e envolvente. Apesar de ser um sambacanção, o arranjo leve e inovador de Jobim destoa dos arranjos pesados da época. Aqui, depois da exposição do tema, vários instrumentos se interpõem e tocam a mesma melodia da voz, porém um de cada vez, proporcionando diferentes timbres ao arranjo. Em "Outra vez" (Jobim) João Gilberto conduz o acompanhamento da música ao violão, já em "Medo de amar" (Moraes) o arranjo torna-se mais denso, compondo bem a interpretação da cantora com a poesia e, finalmente em "Estrada branca" (Jobim/Moraes) Jobim acompanha a cantora ao piano. Nas palavras de Veiga Oliveira: "retornamos à natureza, aos espaços infindos e solitários: "Vou caminhando com vontade de morrer..." Ecos da "Winterreise" schubertiana numa paisagem tropical brasileira?" (OLIVEIRA, 1959).

"Vida bela", para o crítico, "soa quase folclórico em seu modalismo, numa rítmica persistente e sincopada, percussão em destaque. Canção praiana, de matizes africanos" (OLIVEIRA, 1959). De certa forma, esta canção destoa das outras composições do disco, de sambas e canções, imprimindo um ritmo cadenciado, quase nor- destino, precedendo em alguns anos à temática samba/ morro da bossa nova do começo dos anos 1960, com canções da parceria Baden Powel/Vinícius de Moraes ou mesmo Tom Jobim ("0 morro não tem vez"), entre outros. Os acordes menores que se repetem dão essa ideia de modalismo que o crítico escreve. Já a interpretação de "Modinha" (Jobim/Moraes) de Elizete Cardoso só é comparável à de Elis Regina em Elis \& Tom (1974), seja pela interpretação grave e intencional de ambas. Para o crítico:

Chegamos à "Modinha". Que a ninguém iluda o titulo despretensioso. Breve concisa na forma, o conteúdo poético é antes trágico, de um supremo desconsolo. "Não! Não pode mais meu coração viver assim dilacerado, crucificado a uma ilusão que é só desilusão..." Qual segunda voz, paralela e subjacente ao canto, o violoncelo funciona magnificamente como apoio da linha melódica, de uma intensidade expressiva que desafia qualquer descrição (OLIVEIRA, 1959).

Não temos dúvida de que o crítico tem conhecimentos musicais, e que não são poucos. E para conseguir fazer uma análise do disco cercou-se de seus conhecimentos teórico-musicais para conseguir propor uma compreensão acerca da obra. Pensamos, aliás, que é essa qualidade que deve ser valorizada em um profissional do jornalismo musical e é tema de pesquisa desta autora (Bollos, 2007). Como dar conta de uma obra sem 0 conhecimento específico de música? Vimos, acima, que Oliveira se cercou de conhecimentos sobre a canção alemã Lied para fazer um paralelo com o disco de Elizete Cardoso, visto que o próprio crítico se indaga de onde provém aquele disco, do ambiente erudito da música ou do popular. 0 que nos surpreende é que ele, ao comentar cada música, consegue compor o instrumentário de cada faixa magistralmente, propondo uma escuta atenta, construtiva, impensável para os padrões atuais de crítica musical. Aliás, será que não poderíamos afirmar que também para os padrões de crítica musical da época (1959), sua análise era bastante diferenciada? Acreditamos que para escrever críticas jornalísticas na imprensa, não basta somente escrever bem, mas acima de tudo, ter conhecimentos musicais que o ajudem a entender a mensagem da obra. E, para finalizar seu texto, Veiga Oliveira assertivamente afirma:

Por fim, a "Canção do amor demais", que dá o título à coletânea não destoa do caráter conciso, sentido e dolorido da precedente composição. Sobre fundo musical reticente, o violoncelo revela a infinita riqueza de suas possibilidades, ao sustentar todo um edifício harmônico. Palavra e música dão-se idealmente as mãos. A obra de Vinícius-Jobim é um marco da música brasileira contemporânea (Oliveira, 28/02/1959).

Apesar de tentar evitar equiparações entre obras definitivamente incorporadas ao patrimônio artístico universal, Oliveira profetiza sobre a dupla Jobim-Vinícius, "sobre o qual só o tempo dirá de sua permanência no repertório". E parece que o tempo acabou mostrando que o crítico tinha razão, pois a parceria Jobim/Vinícius tornou-se uma das mais importantes obras da música popular brasileira 


\section{Considerações Finais}

Tanto o texto de Vinícius de Moraes na contracapa do disco quanto a crítica de José da Veiga Oliveira para o jornal $O$ Estado de $S$. Paulo reforçam a importância desse disco de Elizete Cardoso para o desenvolvimento da música popular brasileira. Ambos demonstram que a fronteira existente entre o popular e erudito fica menos evidente por conta do alto grau composicional das canções e pelos arranjos assinados por Jobim. Não por acaso esses dois textos de Vinícius de Moraes e Veiga Oliveira são colocados lado a lado neste trabalho a fim de que vários aspectos, sobretudo musicais, possam ser avaliados em Canção do amor demais.

0 primeiro por ser um dos mentores do disco, autor de letras e de várias músicas, mas também pela representatividade que tem diante da cultura brasileira, de modo geral. Na capa do disco aparece ao lado do nome de Vinícius de Moraes o termo poesia ao invés de letra, da mesma forma no seu texto da contracapa do disco. Já Oliveira impõe à crítica musical um olhar respeitoso diante do disco, o que colabora para a boa compreensão deste dentro do campo jornalístico, despertando interesse em conhecer esta nova obra. Mas, principalmente, por Veiga Oliveira ser um musicólogo e por atuar na imprensa escrita como crítico de um dos mais importantes jornais brasileiros na época, o jornal $O$ Estado de $S$. Paulo. Ambos perceberam a relevância do disco, tanto do ponto de vista histórico quanto estético, por emergir justamente no momento anterior que o fenômeno bossa nova, propondo um olhar atento às invenções e inovações que estavam surgindo.

Mais do que o disco de apresentação da bossa nova, porque, afinal, três grandes mentores do movimento musical em constituição estavam juntos no mesmo projeto, Tom Jobim, Vinícius de Moraes e João Gilberto (como músico), Canção do amor demais é o marco que colaborou para renovar a música popular brasileira. Poucos anos depois o movimento bossanovista viria a se tornar um sucesso internacional sem precedentes na história da nossa música, demonstrando que sambas e canções podem ser levados a sério, com rigor e leveza, onde palavra e música dão-se idealmente as mãos.

\section{Referências}

BANDEIRA, Manuel. Literatura de Violão. Revista da Música Popular, Rio de Janeiro, n. 10, out. 1955.

BOLLOS, Liliana Harb. Um exame da bossa nova pela crítica jornalística: renovação na música sob o olhar da crítica. Tese de Doutorado. PUC-SP, São Paulo, 2007.

CABRAL, Sérgio. Antônio Carlos Jobim: uma biografia. Rio de Janeiro: Lumiar, 1997.

CARDOSO, Elizete. Canção do amor demais. Festa. FT 1801. 1958. 1 CD.

CASTRO, Ruy. Chega de saudade. 3. ed. São Paulo: Companhia das Letras, 2002.

GILBERTO, João. Chega de saudade. Rio de Janeiro: EMI-Odeon, 1959. 1 CD.

JOBIM, Antônio Carlos. Texto da contracapa do disco Chega de saudade. Rio de Janeiro: EMI-Odeon, 1959.

MORAES, Vinicius. Certidão de nascimento III. Diário Carioca, Rio de Janeiro, 29 jan. 1965.

. "Canção do amor demais". Texto na contracapa do disco. Festa. FT 1801. 1958.

OLIVEIRA, José da Veiga. Canções e modinhas nossas. Suplemento Literário. O Estado de S. Paulo, 28 fev. 1959.

RODRIGUES, Caetano; GAVIN, Charles. Bossa Nova e Outras Bossas: A Arte e o Design das Capas dos LPs. São Paulo: Viva Rio/Petrobrás, 2005.

Liliana Harb Bollos é Doutora em Comunicação e Semiótica (PUC-SP, 2007), Mestre e diplomada em Performance / Piano Jazz pela Kunst Universität Graz, Áustria (1996) e Bacharel e Licenciada em Letras (USP, 1987). Desde 1999 é professora da Faculdade de Música Carlos Gomes onde leciona piano popular, língua portuguesa, harmonia popular e prática instrumental pedagógica. É professora de harmonia popular e percepção no Conservatório de Tatuí e é professora de história da música popular e pianista correpetidora da EMESP Tom Jobim. Como pianista já se apresentou com Al aíde Costa, Mark Murphy, Orquestra Sinfônica de Santo André e Duo Fel, Fernando Corrêa Quarteto, Coralusp e Ruy CastroSabá Quinteto, entre outros. Foi professora de piano popular do Festival de Música de Ourinhos (2005) e do Curso de Férias de Tatuí (2007). Com o Quarteto Imago (com Renato Correa, Watson Clis e Fernando Corrêa) já atuou no Festival de Inverno de Ouro Preto (2007), no Projeto SESI Música (Araraquara, Franca e Rio Claro, 2007) e em várias unidades do Sesc. É integrante do Quarteto Sonoro (com Daniel Allain, Fernando Corrêa e Sérgio Schreiber) com o qual foi um dos grupos premiados pelo ProAc da Secretaria de Estado da Cultura de São Paulo. Tem publicado diversos artigos em revistas (Opus, Contemporânea, Música Hodie, Revista Comunicação \& Sociedade, entre outras) e livros (Ensino, música e interdisciplinaridade e Faculdade de Música Carlos Gomes). 